Running head: HYMNARY.ORG: THE USE OF A NEW DATABASE IN HYMNOLOGY

Hymnary.org: The Use of a New Database in Hymnology

\begin{abstract}
Author Note
Tina Schneider, University Libraries, The Ohio State University at Lima

Harry Plantinga, Department of Computer Science, Calvin College
\end{abstract}

This research was supported in part by a grant from the National Endowment for the Humanities as part of the Endowment's We The People initiative. Any views, findings, conclusions, or recommendations expressed in this publication do not necessarily reflect those of the National Endowment for the Humanities.

Correspondence concerning this article should be addressed to Tina Schneider, Library, The Ohio State University at Lima, 4240 Campus Dr., Lima, Ohio, 45804. Contact: schneider.290@osu.edu. 


\title{
HYMNARY.ORG: THE USE OF A NEW DATABASE IN HYMNOLOGY
}

\begin{abstract}
Hymnary.org is a large hymnological database that provides information about thousands of hymnals and millions of hymn instances. It has media files and nearly 2,000 scanned hymnals. The authors conducted a user survey between August 1, 2011 and January 31, 2012 to determine a typical user profile and user expectations of Hymnary.org. Respondents were asked to provide information about themselves, their interest in hymnody, how they found Hymnary.org, how they used it, and whether the database met their information needs. The survey revealed that frequent users are most commonly involved with worship planning, followed by users with an academic interest in hymnological information. The primary entry point to Hymnary.org was a search for a specific hymnal, and users were interested in both text and tune information. Users show a need to understand the limitations of copyright, and to be made aware of the commercial hymn arrangements available via Hymnary.org.
\end{abstract}

Keywords: Hymns, hymnology, database, user survey

Hymnary.org: The Use of a New Database in Hymnology 


\section{HYMNARY.ORG: THE USE OF A NEW DATABASE IN HYMNOLOGY}

\section{Introduction}

Hymnary.org is a large database of hymnody, offering information about hymn texts, tunes, hymnals, authors, and composers. It offers background information, media files, and other resources for these entities and enables users to search by flexible criteria. Founded in 2007, Hymnary.org is designed to serve two diverse audiences: worship leaders and hymnology scholars.

In 2010, Hymnary.org was awarded a two-year grant from the National Endowment for the Humanities (NEH) to incorporate the Dictionary of North American Hymnology (DNAH). The DNAH, a 60-year-old project of The Hymn Society in the United States and Canada, indexed the first lines of the hymns included in nearly 5,000 hymnals published through 1979. Hymnary.org has expanded this coverage to contemporary hymnals, tune data, and encyclopedic information. The NEH grant also made possible the scanning of nearly 2,000 hymnals from the Benson collection at the Princeton Theological Seminary, and it supported the addition of powerful searching and other capabilities to support the needs of scholarly researchers.

Hymnology presents unique challenges for database and user interface design. Hymn texts may be set to different tunes in different hymnals, and hymn tunes may be used for multiple texts. Editors, composers, arrangers, authors, and those who sing hymns have traditionally felt free to adjust tunes and texts as they see fit. Words are changed or retranslated, notes are changed, refrains are added or modified, and stanzas are rearranged, added, or deleted, so that texts and tunes have different versions, editors, translators, and arrangers in different hymnals. Scholarly researchers are typically interested in viewing and searching all of these bibliographic and historical details. Worship leaders are typically looking for texts by name, topic or scripture reference, and they are seeking modern texts and tunes with associated resources such as musical 
HYMNARY.ORG: THE USE OF A NEW DATABASE IN HYMNOLOGY

arrangements, PowerPoint files, or recordings, rather than publication and edition history. We attempted to design a system that both types of users would find easy to understand yet sophisticated enough to handle their needs.

The history and development of this database have been discussed elsewhere (Plantinga \& Schneider, 2010). The intent of the present study is to learn about the users of Hymnary.orgwho they are and how they find and use the database. We also wanted to assess how successful we were at meeting the different needs of the two diverse audiences. Data for this study was gathered from Google Analytics and from a survey presented on the Hymnary.org website from August 1, 2011 to January 31, 2012.

\section{Literature Review}

Very few extant databases cover both hymn texts and tunes for scholarly purposes. The Dictionary of North American Hymnology, now folded into Hymnary.org, focused on first lines only. Websites such as CyberHymnal, Nethymnal.org, and Hymns.net do cover texts and tunes, but they are not targeted at scholarly use and they often do not cite the sources of information.

The Hymn Tune Index (HTI) is the only other online, currently maintained scholarly database providing information about hymn texts and tunes. Housed at the University of Illinois at Urbana-Champaign, the HTI was formally begun in 1982 by Nicholas Temperley, and has as its goal to be a "comprehensive census of tunes associated with English-language hymns 5 found in sources printed in or before the year 1820." (Temperley, n.d.) The HTI is searchable by incipit, text, source, and composer, and the website provides detailed instructions on how best to

\footnotetext{
${ }^{5}$ By "English-language tunes," Temperley indicates that "various hymn tunes published in English-speaking countries, but only with Latin, Dutch, German, Italian, or Welsh texts, have been excluded. On the other hand, tunes published for use with English texts in France, Holland, India, Wales, and the Genevan Republic have been indexed." (Temperley, n.d.)
} 


\section{HYMNARY.ORG: THE USE OF A NEW DATABASE IN HYMNOLOGY}

use its coding systems. This database was printed as a four-volume set in 1998 and earned the highest accolades from scholars in hymnology and musicology.

\section{W. Daniel Landes' and Mark G. Putnam’s CD-ROM The Electronic Encyclopedia of} Hymnology (2000) is the only other searchable database of hymn tunes and hymn texts. Covering fifteen hymnals, most from the 1980s and 1990s, it is searchable by nearly all of the fields also available at Hymnary.org: title, author, year, meter, tune name, keyword, and tune contour. Like Hymnary.org, it includes encyclopedic information, drawn from respected hymnological works such as Sing with Understanding (Eskew \& McElrath, 1995) and the handbook to The Baptist Hymnal (1992).

Other resources in hymnology are in print only. John Julian's A Dictionary of Hymnology, (1892, supplement 1907) is the longstanding classic in the field. Julian's work focuses on English-language publications, and was the first major work to supply information about the history of hymn texts and their authors. ${ }^{6}$ Katharine Smith Diehl's Hymns and Tunes: An Index (1966) analyzes the texts and tunes to seventy-eight hymnals, searchable by first line, author, tune name, composer, and melody. The last work that should be mentioned here is D. DeWitt Wasson's enormous, three-volume Hymntune Index and Related Hymn Materials. This work focuses exclusively on hymn tunes found in over 2000 publications of keyboard arrangement of all kinds, and 432 hymnals. $^{7}$

\section{Methods}

To learn what we could about the users of Hymnary.org, we used two primary tools: Google Analytics, a sophisticated tool for analyzing website usage based on website access data

\footnotetext{
${ }^{6}$ The forthcoming Canterbury Dictionary of Hymnology is intended to be a successor to Julian, and will be available online (Canterbury Dictionary of Hymnology, 2010).

${ }^{7}$ Data from seventy of these hymnals was taken from Diehl's Hymns and Tunes (Wasson, 1998).
} 
and Google's knowledge of the users, and a custom survey that we administered to volunteer Hymnary.org users between August 1, 2011 and January 31, 2012. The survey was offered to database users by a prominent invitation on the Hymnary.org home page. In addition, an announcement of the availability of the survey was made in The Verse, an online newsletter of the Hymn Society in the United States and Canada (The Hymn Society, 2011). There were 217 survey respondents. Survey results may be found in Appendix A.

Since survey respondents were self-selected, it is reasonable to ask how similar they are to average users of the database. One way to judge the similarity is to compare frequency of use. As discussed in the results section below, frequency of use for survey respondents is much higher than that reported by Google Analytics, indicating that survey respondents were heavily biased toward frequent users, probably those with a professional or significant avocational interest in the topic.

\section{Results}

\section{User profile}

Questions one through three of the Hymnary.org survey attempt to determine who our users are. The first question asks about occupation or status as a student, and provides several options along with an

Question 1. Which one description best describes who you are?

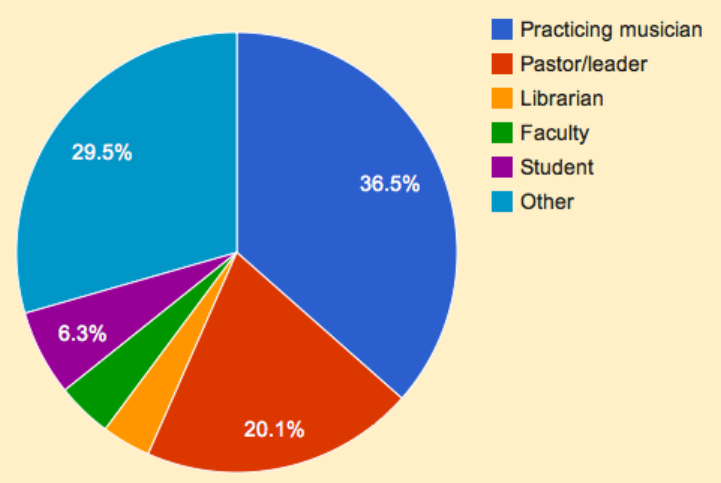
option to write in an answer. From the responses given, it is evident that at least $56 \%$ of respondents are involved in leading church worship. However, some of the answers marked "other," with specific occupations written in, match the options already given. For example, a person wrote that he or she is a "musical leader 
HYMNARY.ORG: THE USE OF A NEW DATABASE IN HYMNOLOGY

in congregation," fitting the "practicing musician serving a congregation" category. With these answers taken into account, it appears that $64.1 \%$ of respondents are using Hymnary.org in the context of church worship. Just over $20 \%$ are using Hymnary.org for hymnology research (14.3\% academic, $6.9 \%$ publisher or independent). Within the academic categories, the largest are graduate students in theology and music faculty members, which number $3.2 \%$ and $2.8 \%$ respectively.

Questions two and three ask about sex and age. Sixty-seven percent of respondents were male, $33 \%$ female. About $34.9 \%$ of M Div students were female in fall 2009, (Lindner, 2011, p.385) and according to the National Congregations Study, women lead about $8 \%$ of congregations nationwide on average, although this can

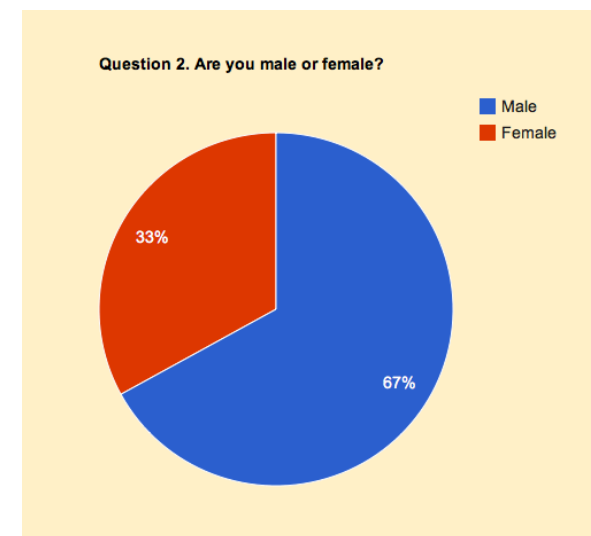
vary widely among denominations (Chaves, 2009). Taken together, that would indicate that among our theologically-trained users, the majority-male audience for Hymnary.org would not come as a surprise. There does not appear to be a study that evaluates the profile of church musicians, so it is not possible to see if the 2-to-1 ratio holds among our largest group of users. It is interesting to note, though, that, among known private collectors of sizable hymnal collections, that is, those who have demonstrated a strong bibliographic interest in hymnals, the ratio of men to women collectors has been roughly 3.5 to 1 (Schneider, 2003). ${ }^{8}$

Questions two and three ask about sex and age. Sixty-seven percent of respondents were male, 33\% female. About 34.9\% of M Div students were female in fall 2009, (Lindner, 2011,

\footnotetext{
${ }^{8}$ Twenty-six men had private collections listed, seven women, and two couples. It should be noted that these are self-reporting owners of hymnal collections, and in recent years some of these privately held collections have been donated to institutions.
} 


\section{HYMNARY.ORG: THE USE OF A NEW DATABASE IN HYMNOLOGY}

p.385) and according to the National Congregations Study, women lead about $8 \%$ of congregations nationwide on average, although this can vary widely among denominations (Chaves, 2009). Taken together, that would indicate that among our theologically-trained users, the majority-male audience for Hymnary.org would not come as a surprise. There does not appear to be a study that evaluates the profile of church musicians, so it is not possible to see if the 2-to-1 ratio holds among our largest group of users. It is interesting to note, though, that, among known private collectors of sizable hymnal collections, that is, those who have demonstrated a strong bibliographic interest in hymnals, the ratio of men to women collectors has been roughly 3.5 to 1 (Schneider, 2003). ${ }^{9}$

By far the largest age group was that of

Question 3. What is your age?

$40 \%$

the total. Next largest was the 60-69 range

(19.7\%), followed by those ages 40-49

$(16.4 \%)$.

Finding and using the database
$30 \%$

$20 \%$

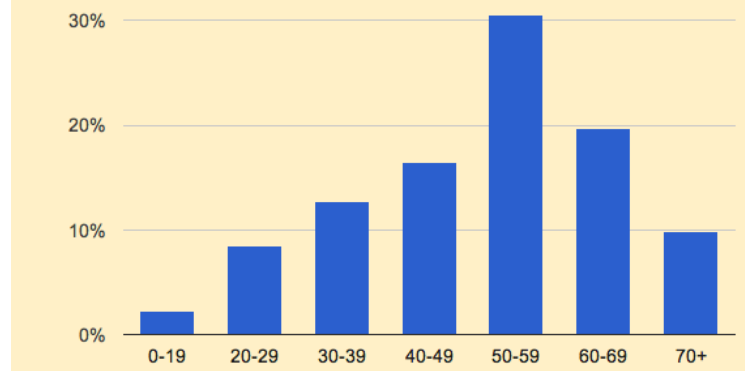

The next few questions address the usage of Hymnary.org. Here, in addition to the survey, Google Analytics is very helpful - it offers many details on the usage of the database. In March 2012, the database received 1,049,867 page views across 165,460 visits. Approximately 5,500 visitors per day viewed 6.35 pages per visit, spending an average of 2 minutes, 43 seconds on site. $61 \%$ of the traffic was from the United States, $12 \%$ from the United Kingdom, $5 \%$ from

\footnotetext{
${ }^{9}$ Twenty-six men had private collections listed, seven women, and two couples. It should be noted that these are self-reporting owners of hymnal collections, and in recent years some of these privately held collections have been donated to institutions.
} 
Canada, and the remaining 18\% from 199 other countries. Although there is as yet no mobile version of Hymnary.org, $8.4 \%$ of visits were from mobile devices.

Question 4 addresses how users find the database. Although much effort has been expended in publicizing Hymnary.org to appropriate audiences, the large majority of users find the database through Google. They are interested in a hymn text or tune, or a hymnal, and they type its name into Google.

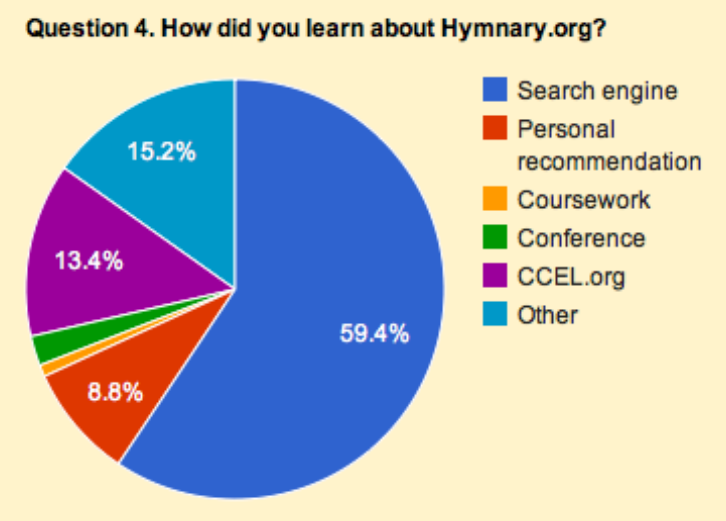
According to Google Analytics, 87.0\% of traffic originated from a search engine in March 2012, with the remainder arriving through referring sites $(5.2 \%)$ or directly, e.g. by a bookmark or typing a URL into a browser (7.8\%). Of the visits originating from search engines, $86 \%$ originated from Google. About half of the top 50 Google search queries were hymnal names. The rest were hymn text names and a few hymn tune names. The large proportion of visits resulting from Google searches for hymnal names (vs. hymn text or tune names) probably results from the fact that there are fewer Web pages about hymnals. A lower percentage of the survey respondents $(59 \%)$ reported finding the site through search engines, probably because of the bias among survey respondents toward heavy users.

The predominance of Google as a source of traffic underscores the importance of search engine optimization. Users find such databases by searching for keywords. In order to make a database like this discoverable, it must be structured so that its pages rank highly in Google searches for those keywords. 
Question 5 addresses the frequency of use of the database. Here Google Analytics and our survey give somewhat different results. Google Analytics provides a metric entitled Visitor Loyalty, defined as the lifetime count of visits (including the current visit) from visitors in March 2012:

\section{Lifetime Visits}

$201+$ times

51-200 times

15-50 times

6-14 times

2-5 times

1 time

\section{Proportion of Visitors}

$0.6 \% \quad$ (980 visitors)

$1.2 \% \quad(1,924$ visitors $)$

$3.6 \% \quad(5,933$ visitors $)$

$6.2 \% \quad(10,181$ visitors $)$

$23.6 \%(39,032$ visitors $)$

$64.9 \%(107,410$ visitors $)$

Responses to Question 5 indicate

that $21.9 \%$ of survey respondents used the site significantly less than once a month. This group may perhaps be compared to users who visited the site up to five times according to Google Analytics, i.e. 88.5\% of users. On the other hand, $42.3 \%$ of the

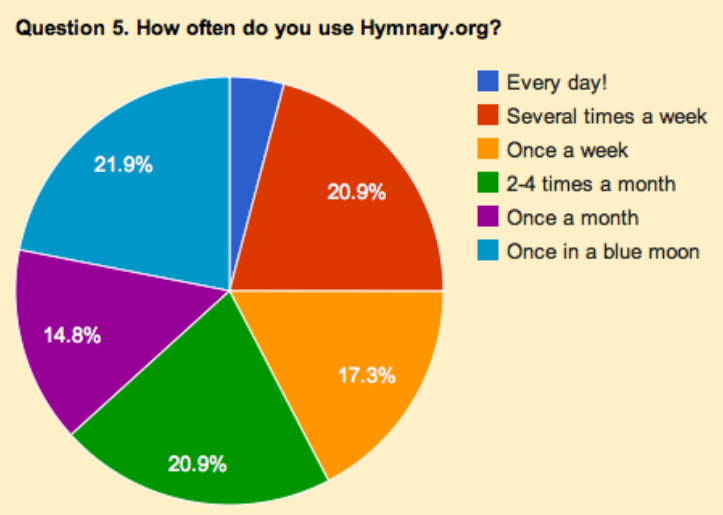
survey respondents report using the database at least weekly, and $1.8 \%$ of visitors have visited the site at least 51 times according to Google Analytics. Thus the survey respondents were heavily biased toward frequent users.

\section{Worship Style}


HYMNARY.ORG: THE USE OF A NEW DATABASE IN HYMNOLOGY

Question 6 attempts to learn something about the worship style of churches using Question 6. In what other hymn-related organizations is your church a member?

$80 \%$

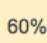

$60 \%$

$40 \%$

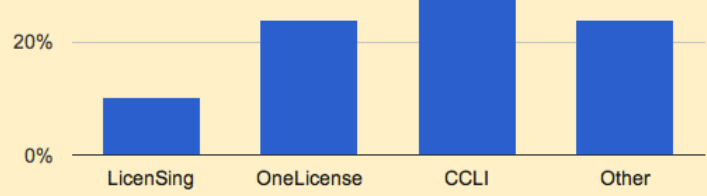
worship). Christian Copyright Licensing International (CCLI) is an organization that serves users of contemporary praise and worship music. It acts as a copyright clearinghouse, so that subscribing churches pay an annual fee for permission to use all CCLI-licensed music, which encompasses the vast majority of contemporary praise and worship music. In addition, the CCLI website has come to serve as a place to discover and find resources for this music.

One part of Hymnary.org's mission is to provide CCLI-like resources for hymnody. Thus, one might expect Hymnary.org's users to be predominantly traditional hymn users who want to search their own hymnal, find texts for projection, or find related resources. On the other hand, congregations that mainly use traditional hymns normally have hymnals in the pews from which hymns are selected, and they may not have much need for a resource like Hymnary.org unless the worship planners or church musicians are looking for supplementary materials.

The responses to question 6 indicate that $69.4 \%$ of survey respondents are in churches that are members of CCLI. This suggests that most of those who use Hymnary.org for worship planning use blended worship. It may be that these congregations don't have hymnals in the pews or that they want to find words and music to hymns to project on overhead screens. 
Question 7 asks about the types of purchases made by respondents - information that can also shed light on worship styles and the needs of users. Because the largest groups of users include musicians serving a congregation and congregational leaders, it is not surprising to see that many of them purchase books on worship (46\%) and choral and keyboard/organ arrangements (41.6\% and 42.2.\%). Many of the "other" responses indicated a need to find hymn texts to display during a worship service.

Question 8 addresses more directly the purposes and needs of the users of the database. This question asks, "What are your reasons for using Hymnary.org?" Users were permitted to choose multiple responses. More than half of the survey respondents $(57 \%)$ used the database for worship planning. An even larger proportion (61.6\%) used it for research of some type. Within the research categories, independent research by users

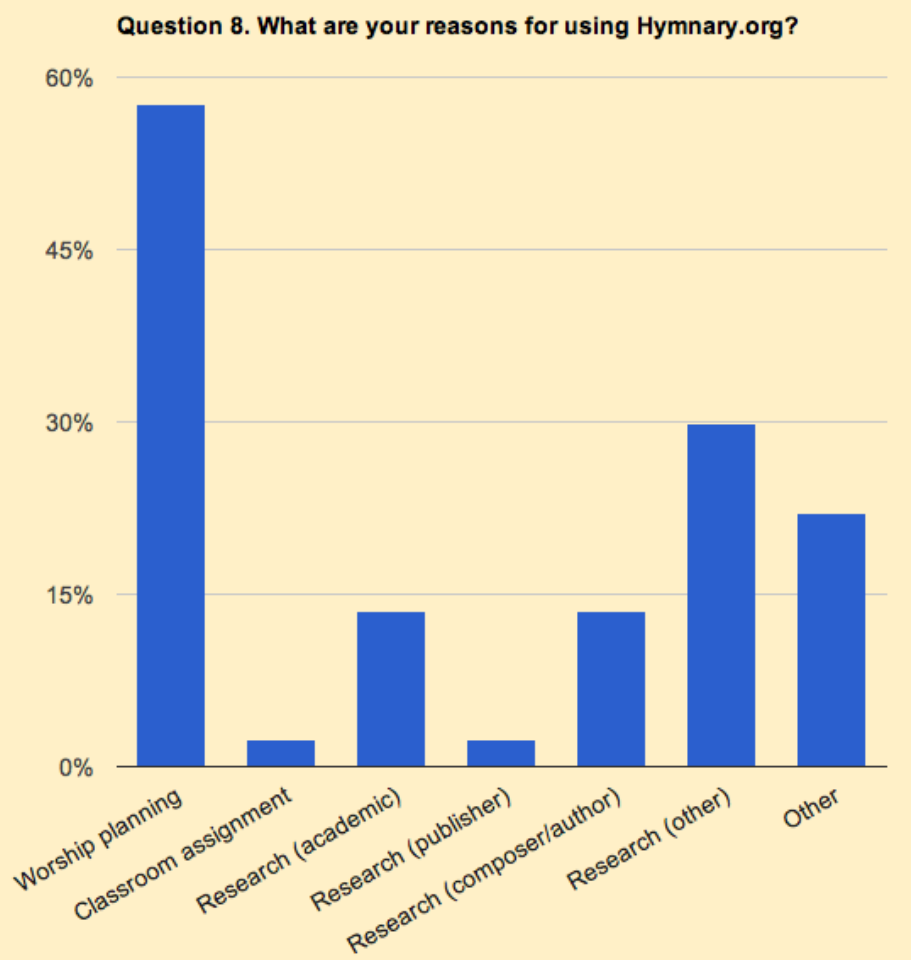
who did not fit a particular category of student, faculty member, composer, etc. represented nearly half at $29.8 \%$ of respondents. Among academics, faculty and graduate students use the database most (12.5\%). Composers and hymn text writers constituted $13.5 \%$.

Question 9 looks more closely at the features of Hymnary.org used most frequently. Of the four major entity types represented in the database - texts, tunes, people, and hymnals- 
HYMNARY.ORG: THE USE OF A NEW DATABASE IN HYMNOLOGY

respondents reported

searching for text and tune

Question 9. What do you typically do at Hymnary.org?

information $71.8 \%$ and

$68 \%$ of the time. Hymnal

information was third,

with just under half of the

users searching in that

area, and person

information was last with

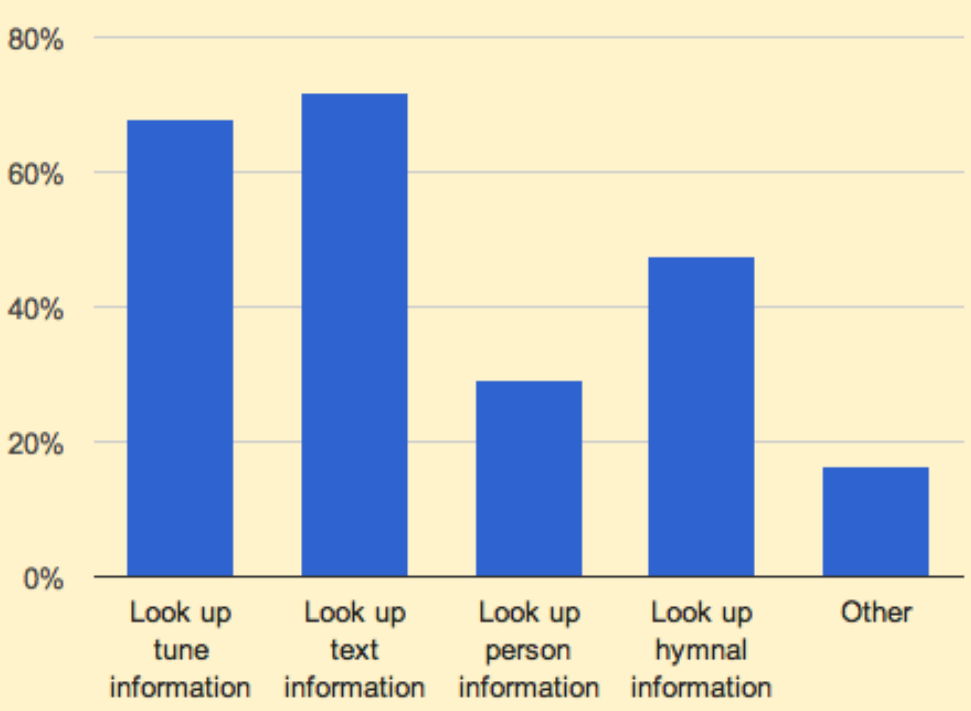

29.1\%. Access logs for March 2012 indicate that for page views of text authority, tune authority, author/composer pages, and pages of hymnals, text authority pages received about $19.8 \%$ of the pageviews, tune authority pages $7.5 \%$, author/composer pages $3.6 \%$, and pages of hymnals 69.0\%. Thus, most users viewed text and tune instances, i.e. as published in particular hymnals, rather than authority pages which have information about all instances of texts or tunes.

\section{Website Functionality}

Question 10 offers survey respondents an opportunity to say what they like about Hymnary.org and to offer suggestions for additions or changes. This kind of feedback is essential for improving usability and for planning additional features. It also helps us get a sense of whether we are striking an appropriate balance between the needs of our two primary target audiences, researchers and worship planners. Our biggest challenge is ease of use. Researchers often require more detailed bibliographic and historical information, whereas worship leaders and the casual user often more point-of-use information related to practice. 


\section{HYMNARY.ORG: THE USE OF A NEW DATABASE IN HYMNOLOGY}

Of 100 survey participants who gave specific responses to this question, $40 \%$ named comprehensiveness as what they liked best about Hymnary.org, and the second-favorite feature was ease and speed of use, named by $21 \%$ of respondents. Considering that a large proportion of our users are worship leaders, this suggests that we have done at least a decent job of making the resource easy to understand and use. Written comments by respondents were broadly varied, with more positive comments than negative about ease of use and intuitiveness. Responses to search capabilities were equally balanced between those who mentioned the search capabilities as the most valuable feature and those who suggested enhancements for search capabilities. There were no comments suggesting search capabilities needed for research that are lacking. These responses suggest that we have largely managed to satisfy the needs of the two diverse clientele, at least for survey respondents. However, survey respondents are frequent users. Continued effort at simplifying and clarifying the interface may benefit less-frequent users.

Other user suggestions include bookmarks, guitar chords, and requests for more of just about everything, especially audio files, scores in open formats, and more resources for reprinting or projection. Here copyright and licensing issues arise for modern hymnals. However, the largest copyright holder of hymnody, Hope Publishing, has given us permission to display their texts and tunes.

While grants were received to build this database, a continuing source of revenue will be needed to continue operation when grants end. To that end the site has advertising and offers resources for sale to worship leaders. A store offers product search and browsing, and hymn text and tune authority pages offer related products such as arrangements, scores, and PowerPoints of interest to worship leaders. According to the results of Question 11, only 3.9\% of survey respondents had made a purchase at the Hymnary.org store. A distressingly large number of 


\section{HYMNARY.ORG: THE USE OF A NEW DATABASE IN HYMNOLOGY}

written responses indicated that respondents weren't even aware of the existence of a Hymnary.org store. Apparently we have succeeded in preventing the e-commerce aspect of the site from becoming too overbearing. However, we will need more awareness of the products offered in order to sustain the site.

\section{Discussion}

Hymnary.org has as its mission to serve both the practical and the scholarly needs of those who use hymns regularly in worship services and those who research the history of hymn texts and tunes. As we have seen, the greatest number of frequent users are church musicians and congregational leaders, mostly between the ages of 40 and 69 , although there are healthy representations of all adult age groups. A number of people have made Hymnary.org a frequent destination, perhaps a fundamental part of the work they do, with 980 visitors in March 2012 who had visited the site over 200 times. On the other hand, nearly two thirds of visitors in that month (64.9\%) visited only once.

With this user profile, one might expect the usage of the database to heavily favor worship planning over other uses. Certainly worship planning holds a large percentage of the primary usage of Hymnary.org, but it is interesting to note that research needs of both academics and others represent an equally large percentage of usage. Among frequent users, Hymnary.org seems to be maintaining a remarkably good balance between the practical needs of providing information for worship services and the scholarly uses of hymnological data.

Although many users come to Hymnary.org via a Google search for a hymnal by name, page view statistics suggest that they are ultimately searching for a hymn text or tune. Frequent users look up tune and text information at nearly equal rates, which is interesting because the vast majority of the data from the Dictionary of North American Hymnology did not include 


\section{HYMNARY.ORG: THE USE OF A NEW DATABASE IN HYMNOLOGY}

tune information. This suggests that the tune data being added to Hymnary.org for both older and newer hymnals adds value for our users and may lead to a greater number of users over time.

User comments are clear in expressing the desire for the availability of recordings, texts, scores, and page scans for use in worship services. The hymnal scans that have been added are almost all in the public domain, published prior to 1923. It appears that Hymnary.org should add media for modern hymnals if possible — and if not possible because of copyright issues, communicate that fact to users. Hymnary.org should also make more obvious the copyrighted resources that are available for sale.

\section{Conclusion}

Hymnary.org fills a unique gap in hymnological research and practice. Users value the ability to search for a combination of hymn text and tune information, as published in particular hymnals. The presentation of information strikes a reasonably good balance between the needs of diverse users. Although copyright law limits our ability to meet all user requests for modern hymnals, licensing arrangements enable us to display many copyrighted texts and tunes, and we hope to be able to address more of these needs. The addition of 2,000 hymnal scans will open up new areas of use, particularly in the field of digital humanities; a future study will surely be needed in this area. 
HYMNARY.ORG: THE USE OF A NEW DATABASE IN HYMNOLOGY

Appendix A: Survey Questions and Answers

Question 1: Which one description best describes who you are?

\begin{tabular}{|c|c|c|}
\hline Answer Options & Response Percent & Response Count \\
\hline practicing musician serving a congregation & $37.7 \%$ & 82 \\
\hline pastor/rabbi/congregational leader & $20.7 \%$ & 45 \\
\hline seminary librarian & $0.5 \%$ & 1 \\
\hline music librarian & $1.4 \%$ & 3 \\
\hline other librarian & $1.8 \%$ & 4 \\
\hline undergraduate student & $1.4 \%$ & 3 \\
\hline theology graduate student & $3.2 \%$ & 7 \\
\hline music graduate student & $1.4 \%$ & 3 \\
\hline other graduate student & $0.5 \%$ & 1 \\
\hline theology faculty member & $0.9 \%$ & 2 \\
\hline music faculty member & $2.8 \%$ & 6 \\
\hline other faculty member & $0.5 \%$ & 1 \\
\hline other (please specify) & $30.4 \%$ & 66 \\
\hline
\end{tabular}

Question 2: Are you male or female?

\begin{tabular}{|l|r|r|}
\hline Answer Options & Response Percent & Response Count \\
\hline female & $33.0 \%$ & 70 \\
male & $67.0 \%$ & 142 \\
\hline
\end{tabular}


HYMNARY.ORG: THE USE OF A NEW DATABASE IN HYMNOLOGY

Question 3: What is your age?

\begin{tabular}{|l|r|r|}
\hline Answer Options & Response Percent & Response Count \\
\hline $0-19$ & $2.3 \%$ & 5 \\
$20-29$ & $8.5 \%$ & 18 \\
$30-39$ & $12.7 \%$ & 27 \\
$40-49$ & $16.4 \%$ & 35 \\
$50-59$ & $30.5 \%$ & 65 \\
$60-69$ & $19.7 \%$ & 42 \\
$70+$ & $9.9 \%$ & 21 \\
\hline
\end{tabular}

Question 4. How did you first learn about Hymnary.org? I found Hymnary.org ... .

\begin{tabular}{|l|r|r|}
\hline Answer Options & $\begin{array}{r}\text { Response } \\
\text { Percent }\end{array}$ & $\begin{array}{r}\text { Response } \\
\text { Count }\end{array}$ \\
\hline Doing a Google (or similar) search for hymn information & $59.4 \%$ \\
When it was recommended to me & $8.8 \%$ \\
Because coursework required me to use it & $0.9 \%$ & 129 \\
After learning about it at a conference & $2.3 \%$ & 2 \\
Through CCEL.org [a sister site] & $13.4 \%$ & 5 \\
Other & $15.2 \%$ & 29 \\
\end{tabular}


HYMNARY.ORG: THE USE OF A NEW DATABASE IN HYMNOLOGY

Question 5. How often do you use Hymnary.org? I use hymnary.org ...

\begin{tabular}{|l|r|r|}
\hline Answer Options & Response Percent & Response Count \\
\hline Every day! & $4.1 \%$ & 8 \\
Several times a week & $20.9 \%$ & 41 \\
Once a week & $17.3 \%$ & 34 \\
$2-4$ times a month & $20.9 \%$ & 41 \\
Once a month & $14.8 \%$ & 29 \\
Once in a blue moon & $21.9 \%$ & 43 \\
\hline
\end{tabular}

Question 6. In what other hymn-related organizations is your church a member? My church is a member of ... (select all that apply)

\begin{tabular}{|l|r|r|}
\hline Answer Options & Response Percent & Response Count \\
\hline LicenSing & $10.2 \%$ & 15 \\
OneLicense.net & $23.8 \%$ & 35 \\
CCLI & $69.4 \%$ & 102 \\
Other & $23.8 \%$ & 35 \\
\hline
\end{tabular}

Question 7. What worship resources do you typically need to obtain? I purchase resources such as ... (select all that apply)

\begin{tabular}{|l|r|r|}
\hline Answer Options & Response Percent & Response Count \\
\hline Choral arrangements & $41.6 \%$ & 72 \\
Musicals (cantatas, etc.) & $17.9 \%$ & 31 \\
Soloist arrangements & $19.7 \%$ & 34 \\
PowerPoint presentations & $13.9 \%$ & 24 \\
Organ/keyboard arrangements & $42.2 \%$ & 73 \\
\hline
\end{tabular}


HYMNARY.ORG: THE USE OF A NEW DATABASE IN HYMNOLOGY

\begin{tabular}{|l|r|r|}
\hline Instrumental accompaniment & $26.6 \%$ & 46 \\
Books on worship & $46.2 \%$ & 80 \\
Handbell arrangements & $9.8 \%$ & 17 \\
Other & $31.2 \%$ & 54 \\
\hline
\end{tabular}

Question 8. What are your reasons for using Hymnary.org? (select all that apply)

\begin{tabular}{|l|r|r|}
\hline Answer Options & Response Percent & Response Count \\
\hline Worship planning & $57.7 \%$ & 120 \\
Classroom assignment (undergraduate) & $0.5 \%$ & 1 \\
Classroom assignment (graduate) & $1.9 \%$ & 4 \\
Independent research (undergraduate) & $1.0 \%$ & 2 \\
Independent research (graduate) & $5.3 \%$ & 11 \\
Independent research (faculty) & $7.2 \%$ & 15 \\
Independent research (music publisher) & $2.4 \%$ & 5 \\
Independent research (composer/author) & $13.5 \%$ & 28 \\
Independent research (other) & $29.8 \%$ & 62 \\
Other & $22.1 \%$ & 46 \\
\hline
\end{tabular}

Question 9. What do you typically do at Hymnary.org? (select all that apply)

\begin{tabular}{|l|r|r|}
\hline Answer Options & Response Percent & Response Count \\
\hline Look up tune information & $68 \%$ & 140 \\
Look up text information & $71.8 \%$ & 148 \\
Look up person information & $29.1 \%$ & 60 \\
Look up hymnal information & $47.6 \%$ & 98 \\
\hline
\end{tabular}


HYMNARY.ORG: THE USE OF A NEW DATABASE IN HYMNOLOGY

\begin{tabular}{|l|r|r|}
\hline Other & $16.5 \%$ & 34 \\
& & \\
\hline
\end{tabular}

Question 10. What do you like best about Hymnary.org and/or what do you think is most valuable about Hymnary.org? What would you like to see added or changed at Hymnary.org?

This question gave respondents an opportunity to write in unstructured feedback and suggestions. There were 154 responses to this question.

Question 11. Have you ever made a purchase from the Hymnary.org store? If not, why not?

\begin{tabular}{|l|r|r|}
\hline Answer Options & Response Percent & Response Count \\
\hline Yes & $3.9 \%$ & 8 \\
No & $96.1 \%$ & 198 \\
\hline
\end{tabular}


HYMNARY.ORG: THE USE OF A NEW DATABASE IN HYMNOLOGY

\section{References}

The Canterbury dictionary of hymnology. (2010). Retrieved from

http://hymnology.org.uk/dictionary/Welcome

Chaves, M. (2009, July 13). Why are there (still!) so few women clergy? Duke Divinity Call \& Response blog. Retrieved from http://www.faithandleadership.com/blog/07-13-2009/mark-chaves-why-are-there-still-sofew-women-clergy.

Diehl, K. S. (1966). Hymns and tunes: An index. New York: Scarecrow Press.

Eskew, H. \& H. T. McElrath. (1995). Sing with understanding (2nd ed.). Nashville, TN.: Church Street Press.

Handbook to the Baptist Hymnal. (1992). Nashville, TN.: Convention Press.

The Hymn Society in the United States and Canada. (October 2011). Hymnary.org wants to hear from you! The Verse. Retrieved from http://archive.constantcontact.com/fs078/1104039006581/archive/1108336602501.html\# LETTER.BLOCK63

Julian, J. (1907). A dictionary of hymnology, setting forth the origin and history of Christian hymns of all ages and nations. (Rev. ed., with new supplement). London: J. Murray.

Landes, W. D. \& M. G. Putnam. (2000). The electronic encyclopedia of hymnology [computer software]. Nashville, TN.: Putnam Graphics \& Media Design.

Lindner, E. W. (Ed.). (2011). Yearbook of American \& Canadian churches. Nashville, TN: Abingdon Press.

Plantinga, H. \& T. Schneider. (2010). Updating the Dictionary of North American Hymnology at Hymnary.org. The Hymn, 61 (3), 8-16.

Schneider, T. (2003). Hymnal collections of North America. Lanham, MD: Scarecrow Press. 
HYMNARY.ORG: THE USE OF A NEW DATABASE IN HYMNOLOGY

Temperley, N. (n.d.) Hymn Tune Index. Retrieved from

http://hymntune.library.uiuc.edu/about/scope.asp

Wasson, D. D. (1998). Hymntune index and related hymn materials. (Vols. 1-3). Lanham, MD: Scarecrow Press. 
HYMNARY.ORG: THE USE OF A NEW DATABASE IN HYMNOLOGY

\section{Biographical Sketch}

Tina Schneider is an associate professor and library director at The Ohio State University at

Lima, and is the Director of Research for the Hymn Society in the United States and Canada. She has degrees in music from St. Olaf College and Ohio State, and is on the editorial board of Hymnary.org.

Harry Plantinga is a professor of computer science at Calvin College. His research is in digital libraries, and he is the director of the Christian Classics Ethereal Library (CCEL.org) and Hymnary.org. 